\title{
Moderate hypothermia and responses to calcium channel blockers - Role of the nitric oxide
}

\author{
S Canbolat, KE Nurullahoglu Atalik \\ Meram Faculty of Medicine, Department of Medical Pharmacology, Necmettin Erbakan University, Konya, Turkey
}

Received: February 28, 2017

Accepted: January 24, 2018

\begin{abstract}
Moderate hypothermia $\left(25-31{ }^{\circ} \mathrm{C}\right)$ may have a significant influence on vascular tone. At present, very little is known about the role of endothelial nitric oxide on the hypothermia-induced responses. In this study, we investigated the effect of hypothermia (to $28^{\circ} \mathrm{C}$ ) on the vasodilatation induced by verapamil, a phenylalkylamine calcium channel blocker $\left(10^{-9}-3 \times 10^{-4} \mathrm{M}\right)$ and dihydropyridines, amlodipine $\left(10^{-9}-3 \times 10^{-4} \mathrm{M}\right)$, and benidipine $\left(10^{-9}-10^{-3} \mathrm{M}\right)$ on 5 -hydroxytryptamine (5-HT or serotonin) precontracted calf cardiac veins. Furthermore, the role of nitric oxide in the hypothermia-induced responses was analyzed. Ring preparations of veins obtained from calf hearts were suspended in organ baths containing $15 \mathrm{ml}$ of Krebs-Henseleit solution, maintained at $37{ }^{\circ} \mathrm{C}$, and continuously gassed with $95 \%$ $\mathrm{O}_{2}-5 \% \mathrm{CO}_{2}$. After a resting period, verapamil, amlodipine, and benidipine were applied cumulatively on serotonin $\left(10^{-6} \mathrm{M}\right)$ precontracted calf cardiac vein rings and induced concentration-dependent relaxations. In another part of the study, the medium temperature was decreased to $28^{\circ} \mathrm{C}$ after the preparations were contracted with 5-HT, then cumulative concentrations of verapamil, amlodipine, or benidipine were added. During hypothermia, the $\mathrm{pIC}_{50}$ value, but not the maximal response, to all blockers were significantly higher than at $37{ }^{\circ} \mathrm{C}$. Hypothermia in the presence of $\mathrm{N}^{\mathrm{G}}$-nitro-L-arginine methyl ester (L-NAME, $10^{-4} \mathrm{M}$ ) decreased the $\mathrm{pIC}_{50}$ and $E_{\max }$ values to verapamil, amlodipine, and benidipine. Only one blocker was tested in each preparation. These results suggest that nitric oxide may play a role in the hypothermia-induced changes in vasodilation caused by verapamil, amlodipine, and benidipine in calf cardiac vein, but further research is needed to explain the complete mechanism.
\end{abstract}

Keywords: amlodipine, benidipine, cardiac vein, hypothermia, nitric oxide, verapamil

\section{Introduction}

Hypothermia has been shown to induce significant changes in responsiveness of vascular smooth muscle cells to various drugs $(6,7)$. Most of the previous studies examining the effect of hypothermia on smooth muscle responses have focused on the effects of cutaneous vessels $(13,17,23)$ and information about non-cutaneous vessels is rather limited. Previously, we investigated the effects of hypothermia on diazoxide- (2) and cilostazol-induced (19) relaxations in calf cardiac vein and coronary artery.

Calcium is involved in several vital processes inside the cell, including contractile, secretory, and neural activities. Various stimuli increase the intracellular calcium concentration by mobilization of calcium ions from intracellular stores (endoplasmic reticulum) and/or from the extracellular medium through plasma membrane calcium channels. Among calcium channels present in vascular cells, L-type voltage-gated calcium channels (VGCCs) have been the most described. However, recent studies have shown that T-type VGCCs also play a

\footnotetext{
Corresponding author: K. Esra Nurullahoglu Atalik, $\mathrm{PhD}$

Meram Faculty of Medicine, Department of Medical Pharmacology, Necmettin Erbakan University

Konya 42080, Turkey

Phone: +90 332 2237956; Fax: +90 332 2237952; E-mail: esraatalik@hotmail.com
} 
key role in the control of vascular tone under both physiological and pathophysiological conditions $(4,5)$. Calcium channel blockers inhibit the entry of calcium into the cells of the heart and blood vessel walls, allowing vascular and other smooth muscle cells to relax and result in lower blood pressure (21).

Nitric oxide is an endogenous endothelium-derived vasodilator. Although efforts are currently being made to understand its regulation, production, and function, its role in the effects of hypothermia on vascular responses has not been studied in depth (9). Interestingly, calcium channel blockade with nifedipine increased nitric oxide release by the upregulation of endothelial nitric oxide synthase (NOS) expression. The data further point to enhanced nitric oxide generation as an additional mechanism for the vasodilatory effect of calcium channel blockade (8). In non-cutaneous vessels, very little is known about the role played by nitric oxide in vascular reactivity during moderate hypothermia.

Thus, despite current research to determine the effects of hypothermia on vascular reactivity $(6,7,23)$ of different animal species, studies with vasodilator agents remain incomplete and to our knowledge, there are no studies that analyze the effects of moderate hypothermia on the calcium channel blockers-dependent relaxations.

The purpose of this study was to determine the effects of hypothermia $\left(28{ }^{\circ} \mathrm{C}\right)$ on vascular smooth muscle responses to calcium channel blockers verapamil, amlodipine, and benidipine in calf cardiac vein by analyzing the role of nitric oxide in these effects. This vessel was selected, because this is an easily accessible vessel and is appropriate for studying the direct effects of various agents on the vascular smooth muscle. 5-hydroxytryptamine (5-HT) was used as a contractile agent.

\section{Materials and Methods}

\section{Tissue preparations}

Calf hearts were obtained from a slaughterhouse and were immediately placed in KrebsHenseleit solution (KHS). Segments of the great cardiac veins were removed and cut into rings of $2.5 \mathrm{~mm}$ in length. It originates at the lower or middle third of the anterior interventricular sulcus, turns toward the left side of the atrioventricular groove, and enters the coronary sinus at an angle of approximately $180^{\circ}$ (13). Care was taken not to damage the endothelium. Each ring was mounted in $15-\mathrm{ml}$ organ baths containing KHS, aerated with $95 \% \mathrm{O}_{2}$ and $5 \% \mathrm{CO}_{2}$. KHS was composed of $(\mathrm{mM}): 119 \mathrm{NaCl}, 4.70 \mathrm{KCl}, 1.50 \mathrm{MgSO}_{4}, 1.20$ $\mathrm{KH}_{2} \mathrm{PO}_{4}, 2.50 \mathrm{CaCl}_{2}, 25 \mathrm{NaHCO}_{3}$, and 11 glucose.

Changes in isometric tension were recorded by a force-displacement transducer (BIOPAC MP36, Santa Barbara, CA) connected through amplifiers to an ITBS08 Integrated Tissue Bath System (Commat, Ankara, Turkey). The tissues were allowed to equilibrate for $60 \mathrm{~min}$ under a resting tension of $1 \mathrm{~g}$ with repeated washing every $15 \mathrm{~min}$.

\section{Experimental design}

The endothelial cell integrity was determined in each ring before all experiments. Relaxation responses to acetylcholine $\left(\mathrm{ACh}, 10^{-6} \mathrm{M}\right)$ in rings preconstricted with 5-HT $\left(10^{-6} \mathrm{M}\right)$ were used to test endothelial cell integrity. Preparations that relaxed by $>70 \%$ of the 5 -HT-induced tone after addition of ACh were considered to have undamaged endothelium. Thereafter, experimental procedures were performed as described below. 
After the stabilization period, cardiac vein preparations were contracted with $10^{-6} \mathrm{M}$ 5-HT. After the contraction had reached steady state, verapamil was added to the organ bath cumulatively $\left(10^{-9}-3 \times 10^{-4} \mathrm{M}\right)$ at $37^{\circ} \mathrm{C}$. The maximal 5 -HT contraction was used as a standard by which subsequent responses of the tissue could be expressed (as a percentage of this contraction).

After the first concentration-response curve was completed, preparations were washed and allowed to reestablish resting tension. After the contractile responses to 5-HT, the temperature was changed from 37 to $28{ }^{\circ} \mathrm{C}$ (moderate hypothermia). Hypothermia was rapidly achieved and preparations were allowed to equilibrate at this temperature for $30 \mathrm{~min}$ before the second concentration-response curve was determined for verapamil. Verapamil was prepared daily and added to the organ bath cumulatively.

The influence of nitric oxide on relaxation responses to verapamil was specifically addressed by pretreating the rings with the NOS inhibitor $\mathrm{N}^{\mathrm{G}}$-nitro-L-arginine methyl ester (L-NAME, $10^{-4} \mathrm{M}$ ). Again, after the contractile response to 5 -HT, the temperature was changed from 37 to $28{ }^{\circ} \mathrm{C}$. The tissues were allowed to equilibrate at $28{ }^{\circ} \mathrm{C}$ for $30 \mathrm{~min}$. L-NAME was added to the organ bath $20 \mathrm{~min}$ before concentration-response curves were obtained. Endothelium was not denuded, as only the role of endothelial nitric oxide was examined in this study.

The same procedure was repeated with amlodipine $\left(10^{-9}-3 \times 10^{-4} \mathrm{M}\right)$ and benidipine $\left(10^{-9}-10^{-3} \mathrm{M}\right)$ in different preparations. Amlodipine and benidipine were prepared daily and added to the organ bath cumulatively.

\section{Statistical analysis}

Relaxation responses to calcium channel blockers verapamil, amlodipine, and benidipine are expressed as percentages of the 5-HT-induced $\left(10^{-6} \mathrm{M}\right)$ contractions. Concentrations of verapamil, amlodipine, and benidipine causing $50 \%$ of the maximal response $\left(\mathrm{IC}_{50}\right)$ were calculated from each individual concentration-response curves. Maximal responses $\left(\mathrm{E}_{\max }\right)$ and $\mathrm{pIC}_{50}\left(-\log \mathrm{IC}_{50}\right)$ values for curves [(i) between control at $37^{\circ} \mathrm{C}$ and during hypothermia and (ii) during hypothermia in the absence and presence of L-NAME] were compared.

Student's $t$-test was used to identify statistical differences between two experimental groups. One-way analysis of variance was used to define statistically significant differences between more than two groups. $P<0.05$ was considered statistically significant. Data are shown as mean $\pm \mathrm{SEM}$.

\section{Drugs}

Serotonin creatinine sulfate, L-NAME, acetylcholine chloride, verapamil (all dissolved in distilled water), and amlodipine and benidipine [both dissolved in dimethyl sulfoxide (DMSO)] were used. The concentration of DMSO in the tissue bath was always kept below $0.4 \%$. All drugs were obtained from Sigma (St. Louis, MO).

\section{Results}

Verapamil-induced relaxation

In calf cardiac vein, 5-HT $\left(10^{-6} \mathrm{M}\right)$ produced reproducible contractions. Cumulative addition of verapamil $\left(10^{-9}-3 \times 10^{-4} \mathrm{M}\right)$ produced concentration-dependent relaxation of calf cardiac vein preparations at both 37 and $28{ }^{\circ} \mathrm{C}$ (moderate hypothermia) (Fig. 1). Compared 


\section{Verapamil}

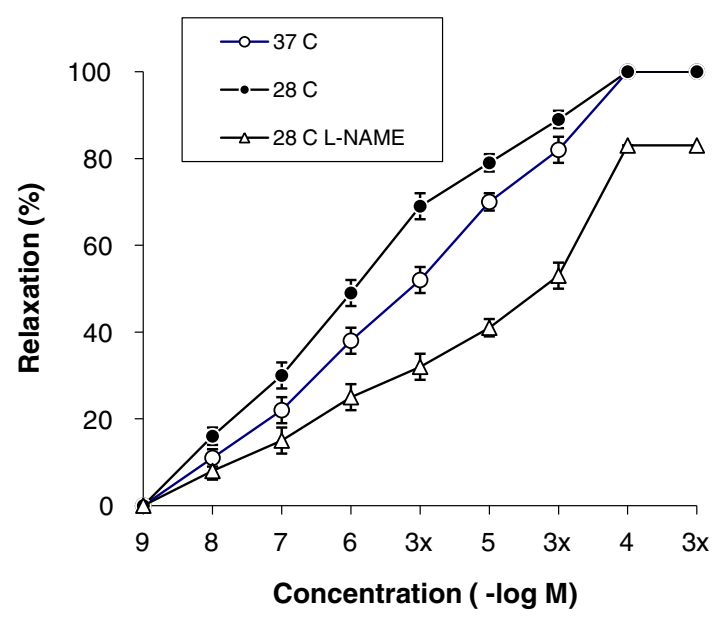

Fig. 1. Relaxation response to verapamil on serotonin $\left(10^{-6} \mathrm{M}\right)$ precontracted calf cardiac vein at 37 and $28^{\circ} \mathrm{C}$, and in the presence of $10^{-4} \mathrm{M}$ L-NAME during moderate hypothermia. Each point is the mean \pm SEM of six experiments

with $37{ }^{\circ} \mathrm{C}$, the $\mathrm{pIC}_{50}$ value of verapamil was significantly higher $\left(\mathrm{pIC}_{50}=5.55 \pm 0.14\right.$ at $37{ }^{\circ} \mathrm{C}$ and $5.98 \pm 0.04$ at $28{ }^{\circ} \mathrm{C} ; P<0.05$ ) during hypothermia (Table I).

Preincubation with L-NAME $\left(10^{-4} \mathrm{M}\right)$ during hypothermia significantly decreased the $\mathrm{pIC}_{50}$ value to verapamil $\left(\mathrm{pIC}_{50}=4.55 \pm 0.40 ; P<0.05\right)$. The basal tone was not affected by treatment with L-NAME at either temperatures $\left(37\right.$ and $\left.28{ }^{\circ} \mathrm{C}\right)$ studied (Table I).

Maximal relaxations to verapamil at 37 and $28{ }^{\circ} \mathrm{C}$ and in the presence of L-NAME at $28{ }^{\circ} \mathrm{C}$ were $100 \%, 100 \%$, and $83 \% \pm 4.0 \%$, respectively. Treatment with L-NAME attenuated the effects of moderated hypothermia on the response to verapamil.

\section{Amlodipine-induced relaxation}

In calf cardiac vein, 5-HT $\left(10^{-6} \mathrm{M}\right)$ produced reproducible contractions and cumulative addition of amlodipine $\left(10^{-9}-3 \times 10^{-4} \mathrm{M}\right)$ produced concentration-dependent relaxation of calf cardiac vein preparations preconstricted with 5-HT at both 37 and $28{ }^{\circ} \mathrm{C}$ (Fig. 2). Compared with $37{ }^{\circ} \mathrm{C}$, the $\mathrm{pIC}_{50}$ value of amlodipine was significantly higher $\left(\mathrm{pIC}_{50}=4.77 \pm\right.$ 0.40 at $37{ }^{\circ} \mathrm{C}$ and $5.74 \pm 0.03$ at $28^{\circ} \mathrm{C} ; P<0.05$ ) during hypothermia (Table I).

Table I. The $\mathrm{pIC}_{50}$ values of verapamil $\left(10^{-9}-3 \times 10^{-4} \mathrm{M}\right)$, amlodipine $\left(10^{-9}-3 \times 10^{-4} \mathrm{M}\right)$, and benidipine $\left(10^{-9}-10^{-3} \mathrm{M}\right)$ on serotonin $\left(10^{-6} \mathrm{M}\right)$ precontracted calf cardiac vein at 37 and $28{ }^{\circ} \mathrm{C}$ and in the presence of $10^{-4}$ M L-NAME during moderate hypothermia

\begin{tabular}{|l|c|c|c|}
\hline pIC $_{\mathbf{5 0}}$ & Verapamil & Amlodipine & Benidipine \\
\hline $37^{\circ} \mathrm{C}$ & $5.55 \pm 0.14$ & $4.77 \pm 0.47$ & $4.53 \pm 0.41$ \\
\hline $28^{\circ} \mathrm{C}$ & $5.98 \pm 0.04^{*}$ & $5.74 \pm 0.03^{*}$ & $5.37 \pm 0.49^{*}$ \\
\hline $28^{\circ} \mathrm{C}-\mathrm{L}-\mathrm{NAME}$ & $4.55 \pm 0.40^{* *}$ & $4.39 \pm 0.29 * *$ & $4.16 \pm 0.41^{* *}$ \\
\hline
\end{tabular}

Values are mean \pm SD. Each value is derived from six experiments.

${ }^{*}$ Statistically significant $(P<0.05)$ compared with value at $37^{\circ} \mathrm{C}$.

${ }^{* *}$ Statistically significant $(P<0.05)$ compared with value at $28^{\circ} \mathrm{C}$ 


\section{Amlodipine}

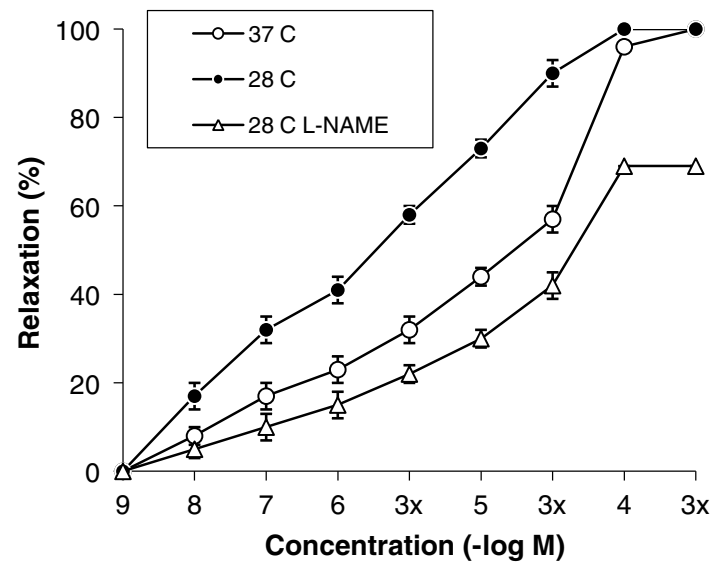

Fig. 2. Relaxation response to amlodipine on serotonin $\left(10^{-6} \mathrm{M}\right)$ precontracted calf cardiac vein at 37 and $28{ }^{\circ} \mathrm{C}$, and in the presence of $10^{-4} \mathrm{M}$ L-NAME during moderate hypothermia. Each point is the mean \pm SEM of six experiments

Preincubation with L-NAME $\left(10^{-4} \mathrm{M}\right)$ during hypothermia significantly decreased the $\mathrm{pIC}_{50}$ value to amlodipine $\left(\mathrm{pIC}_{50}=4.39 \pm 0.29 ; P<0.05\right)$. The basal tone was not affected by treatment with L-NAME at either temperatures $\left(37\right.$ and $\left.28{ }^{\circ} \mathrm{C}\right)$ studied (Table I).

Maximal relaxations to amlodipine at 37 and $28^{\circ} \mathrm{C}$ and in the presence of L-NAME at $28{ }^{\circ} \mathrm{C}$ were $100 \%, 100 \%$, and $69 \% \pm 3.8 \%$, respectively. Treatment with L-NAME attenuated the effects of moderated hypothermia on the response to amlodipine.

\section{Benidipine-induced relaxation}

In calf cardiac vein, 5-HT $\left(10^{-6} \mathrm{M}\right)$ produced reproducible contractions and time-dependent changes were not observed in response to this agent. Cumulative addition of benidipine $\left(10^{-9}-10^{-3} \mathrm{M}\right)$ produced concentration-dependent relaxation of calf cardiac vein preparations precontracted with 5-HT at both 37 and $28^{\circ} \mathrm{C}$ (hypothermia) (Fig. 3). Compared with $37^{\circ} \mathrm{C}$, the $\mathrm{pIC}_{50}$ value of benidipine was significantly higher $\left(\mathrm{pIC}_{50}=4.53 \pm 0.41\right.$ at $37^{\circ} \mathrm{C}$ and $5.37 \pm 0.49$ at $28{ }^{\circ} \mathrm{C} ; P<0.05$ ) at $28{ }^{\circ} \mathrm{C}$ (Table I).

Preincubation with L-NAME $\left(10^{-4} \mathrm{M}\right)$ during hypothermia significantly decreased the $\mathrm{pIC}_{50}$ value to benidipine $\left(\mathrm{pIC}_{50}=4.16 \pm 0.41 ; P<0.05\right)$. The basal tone was not affected by treatment with L-NAME at either temperatures $\left(37\right.$ and $\left.28^{\circ} \mathrm{C}\right)$ studied (Table I).

Maximal relaxations to benidipine at 37 and $28{ }^{\circ} \mathrm{C}$ and in the presence of L-NAME at $28{ }^{\circ} \mathrm{C}$ were $100 \%, 100 \%$, and $72 \% \pm 4.6 \%$, respectively. Treatment with L-NAME attenuated the effects of moderated hypothermia on the response to benidipine.

The maximum inhibitions on the vascular ring contraction to verapamil, amlodipine, and benidipine in the presence of L-NAME were $83 \% \pm 4.0 \%, 69 \% \pm 3.8 \%$, and $72 \% \pm 4.6 \%$, respectively. The order of maximum inhibition was verapamil $>$ benidipine $>$ amlodipine $(P<0.05)$.

\section{Discussion}

In this work, we studied the effects of moderate hypothermia on calcium channel blockersinduced vasodilatation of calf cardiac vein, paying special attention to the role of nitric oxide 


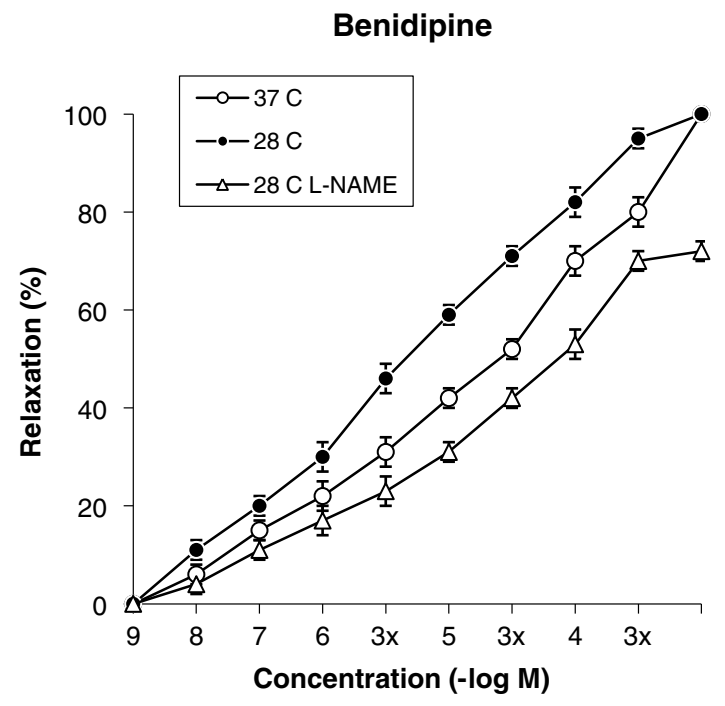

Fig. 3. Relaxation response to benidipine on serotonin $\left(10^{-6} \mathrm{M}\right)$ precontracted calf cardiac vein at 37 and $28{ }^{\circ} \mathrm{C}$, and in the presence of $10^{-4} \mathrm{M}$ L-NAME during moderate hypothermia. Each point is the mean \pm SEM of six experiments

in these responses. The calf cardiac vein is an easily accessible smooth muscle preparation and there is limited information $(12,19,20)$ about the effects of temperature in non-cutaneous vessels. Moreover, the effects of hypothermia were generally studied with contractile agents. Furthermore, to our knowledge, there are no studies that analyze the effects of hypothermia on vascular smooth muscle responses to calcium channel blockers in calf cardiac vein by analyzing the role of nitric oxide in these effects.

The temperature utilized in this study was $28^{\circ} \mathrm{C}$, which was considered to be "moderate hypothermia" in accordance with our earlier studies $(2,3)$.

Our results indicate that at $37{ }^{\circ} \mathrm{C}, 5$-HT induced reproducible contractions in cardiac vein. At this temperature, verapamil, amlodipine, and benidipine induced concentrationdependent vasodilatation in 5-HT precontracted preparations. The main effects of calcium antagonists, as used therapeutically, are on the myocardium and vascular smooth muscle (22). The order of vasodilation activity was verapamil $>$ amlodipine $>$ benidipine, when $\mathrm{pIC}_{50}$ values were compared. In this study, compared with the control responses at $37{ }^{\circ} \mathrm{C}$, hypothermia increased the sensitivity to verapamil, amlodipine, and benidipine. No previous data on the effects of calcium channel blockers of calf cardiac vein during hypothermia have been published. But as the investigators (16) reported that in contrast to the contractile responses in cutaneous vessels, deep vessels dilate when exposed to hypothermia. On the other hand, there are limited and conflicting reports about the effects of hypothermia because of using vasodilator agents and tissues. For example, Fernandez et al. (10) reported that cooling increased the sensitivity of the relaxation of rabbit central ear artery, a cutaneous vessel, but it did not affect the response of the femoral artery, a non-cutaneous vessel, to histamine. It has also been shown that the relaxation to cholinergic stimulation of ear artery, but not of femoral artery, from rabbit was increased during cooling (15).

Nitric oxide is a major factor in the cardiovascular system and plays an important role in maintaining cardiovascular health. Its multiple roles include regulation of vasomotor tone and cell adhesion to the endothelium, inhibition of platelet aggregation, and vascular smooth muscle cell proliferation (1). Although efforts are currently being made to 
understand the regulation, production, and function of nitric oxide, its role in the effects of hypothermia on vascular reactivity has not been studied in depth, and only limited data suggest that changing temperature may also alter the ability of the endothelium to generate or release nitric oxide $(11,14,15)$. In this study, we also investigated the role of nitric oxide in hypothermia-induced responses to verapamil, amlodipine, and benidipine. The sensitivity to the calcium channel blockers studied was decreased by hypothermia in the presence of L-NAME suggesting that the nitric oxide release may be stimulated under hypothermic conditions. Evora et al. (9) demonstrated that the endothelium is sensitive to temperature variations and that the prostacyclin and nitric oxide-dependent pathways may be involved in hypothermia-induced endothelium-dependent vasorelaxation. Previously, we have reported that cooling-induced (to $28^{\circ} \mathrm{C}$ ) changes are independent from nitric oxide to vasodilation caused by diazoxide, isoproterenol, and magnesium sulfate in human umbilical artery (18). The discrepancy between the earlier study and this may be related to the different relaxant agents and tissues used. Furthermore, Mustafa and Thulesius (16) reported that cooling of pulmonary arterial and aortic smooth muscle preparations induced a graded myogenic relaxation inversely proportional to the cooling temperature and the mechanism is not dependent on local nervous or known mediators but related to a direct physicochemical effect of hypothermia. However, no studies have analyzed the role of nitric oxide on calcium channel blockers-induced relaxation during hypothermia of cardiac vein.

In conclusion, the present results suggest that in calf cardiac vein, moderate hypothermia increased the sensitivity to calcium channel blockers verapamil, amlodipine, and benidipine and nitric oxide pathway appears relatively important, as pretreatment with L-NAME decreased the relaxation in response to verapamil, amlodipine, and benidipine.

\section{Acknowledgements}

This study has been supported by the Scientific Research Projects Coordination Unit of Necmettin Erbakan University, Konya, Turkey (project no.: 161318003).

\section{REFERENCES}

1. Andrew JP, Mayer B: Enzymatic function of nitric oxide synthase. Cardiovasc. Res. 43, 521-531 (1999)

2. Atalik KE, Kiliç M, Doğan N: Role of the nitric oxide on diazoxide-induced relaxation of calf cardiac vein and coronary artery during cooling. Fundam. Clin. Pharmacol. 23, 271-277 (2009)

3. Atalik KE, Kiliç M, Nurullahoğlu ZU, Doğan N: Effects of cooling and warming on 5-hydroxytryptamine- and acetylcholine-induced contractions of human umbilical vessels: role of nitric oxide. Fundam. Clin. Pharmacol. 22, 37-44 (2008)

4. Chevalier MG, Gilbert G, Lory P, Marthan R, Quignard JF, Savineau JP: Dehydroepiandrosterone (DHEA) inhibits voltage-gated T-type calcium channels. Biochem. Pharmacol. 83(11), 1530-1539 (2012)

5. Chevalier MG, Gilbert G, Roux E, Lory P, Marthan R, Savineau JP, Quignard JF: T-type calcium channels are involved in hypoxic pulmonary hypertension. Cardiovasc. Res. 103(4), 597-606 (2014)

6. Chung JY, Kim JE, Yoon HJ, Song SY, Kim SO, Roh WS: Moderate hypothermia attenuates $\alpha 1$-adrenoceptor-mediated contraction in isolated rat aorta: the role of the endothelium. Cryobiology 65, 33-40 (2012)

7. Chung YH, Oh KW, Kim ST, Park ES, Je HD, Yoon HJ, Sohn UD, Jeong JH, La HO: Hypothermia inhibits endothelium-independent vascular contractility via Rho-kinase inhibition. Biomol. Ther. (Seoul) 26, 139-145 (2018)

8. Ding Y, Vaziri ND: Calcium channel blockade enhances nitric oxide synthase expression by cultured endothelial cells. Hypertension 32, 718-723 (1998) 
9. Evora PR, Cable DG, Chua YL, Rodrigues AJ, Pearson PJ, Schaff HV: Nitric oxide and prostacyclin-dependent pathways involvement on in vitro induced hypothermia. Cryobiology 54, 106-113 (2007)

10. Fernandez N, García-Villalón AL, Borbujo J, Monge L, García JL, Gómez B, Diéguez G: Cooling effects on the histaminergic response of rabbit ear and femoral arteries: role of the endothelium. Acta Physiol. Scand. 151, 441-451 (2007)

11. Garcia-Villalon AL, Fernández N, Monge L, García JL, Gómez B, Diéguez G: Role of nitric oxide and potassium channels in the cholinergic relaxation of rabbit ear and femoral arteries: effects of cooling. J. Vasc. Res. 32, 387-397 (1995)

12. Guresir MS, Nurullahoglu KE: Role of the nitric oxide on rosuvastatin-induced relaxation of the calf cardiac vein during cooling. Bratisl. Lek. Listy. 115(12), 753-756 (2007)

13. Hodges GJ, Kellogg DL, Johnson JM: Effect of skin temperature on cutaneous vasodilator response to the $\beta$-adrenergic agonist isoproterenol. J. Appl. Physiol. 118(7), 898-903 (2015)

14. Karaki H, Nagase H: Low temperature augments the endothelium-dependent relaxation in isolated rat aorta. Eur. J. Pharmacol. 142, 129-132 (1987)

15. Monge L, García-Villalón AL, Montoya JJ, García JL, Fernández N, Gómez B, Diéguez G: Role of the endothelium in the cholinergic response of rabbit ear and femoral arteries during cooling. Br. J. Pharmacol. 109, 61-67 (1993)

16. Mustafa S, Thulesius O: Cooling is a potent vasodilator of deep vessels in the rat. Can. J. Physiol. Pharmacol. 79(11), 899-904 (2001)

17. Nurullahoglu-Atalik KE, Cenker A: Moderate hypothermia attenuates $\alpha 1$-adrenoceptor-mediated contraction in human varicose spermatic vein: the role of nitric oxide (short communication). Physiol. Int. 103(4), 481-486 (2016)

18. Nurullahoğlu Atalik KE, Nurullahoglu ZU, Kiliç M: Role of the nitric oxide on relaxation of the human umbilical artery during cooling. Yakugaku Zasshi 131(5), 661-667 (2011)

19. Nurullahoglu-Atalik KE, Nurullahoglu ZU, Kiliç M, Aribaş A: Cilostazol-induced relaxation of calf cardiac vein and coronary artery during cooling. Bratisl. Lek. Listy. 114(10), 556-560 (2013)

20. Nurullahoglu ZU: The role of phosphodiesterase activity on the temperature-dependent responses of calf cardiac vein. Bratisl. Lek. Listy. 114(12), 740-743 (2013)

21. Rampe D, Triggle DJ: Ion channels. Drug Dev. Res. 33, 189-372 (1994)

22. Rang HP, Dale MM, Ritter JM, Moore PK (2003): Pharmacology (5th ed.). Churchill Livingstone, Elsevier Science Limited, Edinburgh

23. Zerpa H, Berhane Y, Elliott J, Bailey SR: Cooling augments vasoconstriction mediated by 5-HT1 and alpha2-adrenoceptors in the isolated equine digital vein: involvement of Rho kinase. Eur. J. Pharmacol. 569(3), 212-221 (2007) 